\title{
Acidic Region
}

National Cancer Institute

\section{Source}

National Cancer Institute. Acidic Region. NCI Thesaurus. Code C14068.

Any portion of a protein molecule with a net negative charge. 